Ethnicity and Identity in Ancient Israel 
This page intentionally left blank. 


\section{Ethnicity and Identity in}

\section{Ancient Israel}

Prolegomena to the Study of Ethnic Sentiments and Their Expression in the Hebrew Bible

\section{Kenton L. Sparks}


(C) 1998 by Eisenbrauns.

All rights reserved.

Printed in the United States of America.

Library of Congress Cataloging-in-Publication Data

Sparks, Kenton L.

Ethnicity and identity in ancient Israel : prolegomena to the study of ethnic sentiments and their expression in the Hebrew Bible / Kenton L. Sparks.

p. $\mathrm{cm}$.

Rev. ed. of the author's thesis (University of North Carolina-Chapel Hill, 1996).

Includes bibliographical references and indexes.

ISBN 1-57506-033-7 (cloth : alk. paper)

1. Ethnicity in the Bible. 2. Bible. O.T.-Social scientific criticism.

3. Jews-Identity-History. I. Title.

BS1199.E84S63 1998

$221.8^{\prime} 3058-\mathrm{dc} 21$

$98-44816$

CIP

The paper used in this publication meets the minimum requirements of the American National Standard for Information Sciences-Permanence of Paper for Printed Library Materials, ANSI Z39.48-1984.@ ${ }^{\mathrm{TM}}$ 


\section{To Clive Staples Lewis (1898-1963)}

Though he died in the year of my birth, the fruit of his work freed me from a wearisome agnosticism. 
This page intentionally left blank. 